Instytut Archeologii

Uniwersytet Rzeszowski

Karolina Szpunar

\title{
ŚLADY DZIAŁANIA OGNIA NA STANOWISKACH GÓRNO- I WCZESNOSCHYŁKOWOPALEOLITYCZNYCH W POLSCE ${ }^{1}$
}

Zarys treści. Artykuł dotyczy badań śladów ognia, pochodzących ze stanowisk górno- i wczesnoschyłkowopaleolitycznych z ziem polskich. Zachowane pozostałości to: węgle drzewne, ogniska i przepalone krzemienie, kości, kamienie.

Słowa kluczowe: ogień, paleolit górny, Polska, ogniska.

\section{WSTĘP}

Ogień niewątpliwie stanowi jedną z fundamentalnych zdobyczy człowieka. Pierwsze archeologiczne ślady jego wykorzystywania znane są już $\mathrm{z}$ dolnego paleolitu; odkryto je w Afryce, na stanowiskach datowanych na 1,5-1,0 mln BP (Chesowanja, Jaskina Swartkrans, Kobi Fora) oraz w Izraelu na stanowisku datowanym na 790 tys. BP (Besher Benot Ya'aqov) (Rowlett 2000; Sandgathe i in. 2011; Alperson-Afil 2012). Wykorzystywanie ognia na szerszą skalę miało miejsce znacznie później, bo w okresie funkcjonowania osadnictwa ostatnich neandertalczyków i ludzi anatomicznie współczesnych, co tłumaczy się jako skutek zachodzących wówczas progresywnych zmian (Le feu apprivioisé 1987; Staper, Johansen 1999; Vaquero, Pastó 2001; Roebroeks, Willa 2012).

Przejęcie kontroli nad ogniem nastąpiło w procesie długotrwałej ewolucji. Najpierw podtrzymywano naturalnie powstały ogień, później opanowano sztukę jego niecenia, aż stopniowo zaczęto wykorzystywać go w wielu czynnościach gospodarczych.

Niniejszy artykuł ma na celu zaprezentowanie śladów powstałych w wyniku działania ognia, zidentyfikowanych na obecnych terenach Polski,

\footnotetext{
${ }^{1}$ Serdeczne dziękuję pani Marcie Połtowicz-Bobak za pomoc i opiekę naukową oraz panu Dariuszowi Bobakowi za pomoc techniczną.
} 
datowanych na paleolit górny i wczesnoschyłkowy. Okres ten odpowiada kulturom jerzmanowickiej, szeleckiej, oryniackiej, graweckiej, magdaleńskiej i hamburskiej.

\section{OGIEŃ W PALEOLICIE}

W starszej epoce kamienia człowiek potrafił niecić ogień, posługując się w tym celu dwoma metodami. Pierwszą z nich było tarcie - pocieranie jednym kawałkiem drewna o drugi, drugą zaś uderzanie o siebie dwóch twardych krzemieni lub minerałów żelaza, na przykład pirytu (Le feu apprivioisé 1987; Stapert, Johansen 1999; Pyżewicz, Rozbiegalski 2011; Sorensen i in. 2014). Jako paliwa używano drewna, kości zwierzęcych i węgla. Ten ostatni materiał wykorzystywano prawdopodobnie tylko tam, gdzie występowały jego naturalne złoża. Być może ówcześni łowcy wybierali paliwa w sposób selektywny ze względu na znajomość właściwości i przydatność konkretnych roślin, na przykład sosny, która, podobnie jak inne drzewa iglaste, łatwo się pali (Le feu apprivioisé 1987; Ginter i in. 2002).

Zachowane pozostałości ognisk paleolitycznych pozwoliły na ich podział z uwzględnieniem typu, funkcji, konstrukcji oraz położenia na stanowisku. Ze względu na typ wyróżniono:

- ogniska zagłębione, charakteryzujące się zagłębieniem w sedyment, zwykle na 20-50 cm; duże zagłębienie ogniska mogło być spowodowane próbą ograniczenia zasięgu ognia (Schmieder 1988; Terberger 1997; Leesch i in. 2010);

- ogniska naziemne, umieszczane bezpośrednio na powierzchni sedymentu lub też lekko w niego zagłębione (Schmieder 1988; Terberger 1997);

- ogniska z obstawą kamienną, cechujące się różnymi rozwiązaniami konstrukcyjnymi i tak ogniska mogły mieć obstawę o regularnych układach lub obstawę w formie luźno rozrzuconych kamieni, które nie tworzyły czytelnych struktur (Schmieder 1988; Terberger 1997; Leesch i in. 2010);

- ogniska bez obstawy kamiennej, zaliczono tu wszystkie obiekty bez dodatkowych elementów konstrukcyjnych; są najczęściej spotykane na stanowiskach paleolitycznych (Le feu apprivioisé 1987; Julien 1988; Schmieder 1988).

Ze względu na położenie ognisk na stanowiskach wyróżniono:

- ogniska domowe, zazwyczaj umieszczane w miejscu, będącym centrum obozowiska, mogły też towarzyszyć obiektom mieszkalnym, jak w Dzierżysławiu (stanowisko 35, woj. opolskie) (Ginter i in. 2002; Ginter i in. 2005; Połtowicz-Bobak 2013); paleniska te cechowały się nagromadzeniem sporej 
ilości materiału (kości, kamieni, artefaktów krzemiennych), który z jednej strony świadczy o niegdyś odbywających się tam czynnościach gospodarczych, z drugiej zaś w połączeniu z ich lokalizacją, sugeruje, że miały one dużą rolę społeczną (Schmieder 1988);

- ogniska satelickie, cechują się lokalizacją na peryferiach obozowisk, na przykład jak na stanowisku kultury magdaleńskiej Pincevent we Francji (Julien 1988; Schmieder 1988); ogniska te mieściły się poza główną strefą aktywności łowców; wokół nich odnotowano znacznie mniejsze nagromadzenie artefaktów, co sugeruje, że wykonywano tam raczej czynności bardziej wyspecjalizowane, takie jak przetwarzanie upolowanej zwierzyny, produkcja narzędzi, obróbka skóry etc. (Schmieder 1988).

Ślady działania ognia są trudne do uchwycenia w badaniach archeologicznych. Na stanowiskach spotyka się tylko niektóre elementy wchodzące w skład ognisk - przepalony sedyment, przepalone kości, krzemienie, przegrzane kamienie i węgle drzewne (Daniau i in. 2010; Sandgathe i in. 2011; Alperson-Afil 2012; Roebroeks, Willa 2012). Jedynie przepalony sedyment w obozowiskach paleolitycznych łowców pozwala na jednoznaczne stwierdzenie, że w danym miejscu ulokowane było ognisko (Terberger 1997). Natomiast przepalone kości i krzemienie, niektóre artefakty krzemienne czy kamienie, poddane działaniu wysokiej temperatury mogą świadczyć o różnych czynnościach gospodarczych, na przykład gotowaniu wody, ogrzewaniu szałasu, produkcji narzędzi (Schmieder 1988; Sobczyk 1995; Terberger 1997; Ginter i in. 2002; Leesch i in. 2010).

\section{ANALIZA ŚLADÓW DZIALANIA OGNIA ODNOTOWANYCH NA STANOWISKACH GÓRNO- I WCZESNOSCHYŁKOWO- PALEOLITYCZNYCH W POLSCE}

Ślady działania ognia na ziemiach polskich, pochodzące z górnego paleolitu, odnotowano na 37 stanowiskach kultur górno- i wszesnoschyłkowopaleolitycznych (ryc. 1). Artefakty związane z działaniem ognia w pradziejach to: przepalone krzemienie, węgle drzewne, przepalone kości, przegrzane kamienie, ogniska ze strukturami kamiennymi bądź bez takich struktur oraz rozmyte ślady po potencjalnych ogniskach (tab. 1). Na stan ich zachowania zapewne wpływ miały warunki naturalne, procesy podepozycyjne i niezaawansowane techniki eksploracji w XIX i początkach XX wieku. Wśród wyżej wymienionych znalezisk przeważają węgle drzewne, które zarejestrowano na 28 stanowiskach (76\%). Trzeba jednak zaznaczyć, że te pozostałości nie zawsze 
związane z osadnictwem paleolitycznych łowców, mogły być wynikiem naturalnych pożarów, na przykład po uderzeniu pioruna (Krukowski 1939-1948; Chmielewski 1956; Kozłowski 1964; Dagnan, Ginter 1970; Chmielewski 1975; Dagnan-Ginter 1975; Cyrek 1986; Kozłowski, Kozłowski 1977; Burdukiewicz 1980; Kozłowski, Sobczyk 1987; Le feu apprivioisé 1987; Bocheński i in. 1995; Sobczyk 1995; Cyrek i in. 2000; Cyrek 2002; Ginter i in. 2002; Połtowicz 2004; Wilczyński 2009; Bobak i in. 2010; Cyrek 2010; Alperson-Afil 2012). Kolejną, względnie liczną grupą artefaktów są przepalone krzemienie, odnotowane na 20 stanowiskach (54\%); pozostałe, mniej liczne, to przepalone kości, stwierdzone na siedmiu stanowiskach (19\%) oraz przegrzane otoczaki i kamienne płytki uchwycone jedynie na dwóch stanowiskach (5\%).

Stosunkowo niewielki udział przepalonych kości zwierzęcych mógł być spowodowany przede wszystkim warunkami naturalnymi, ponieważ materiał ten zachowuje się tylko wówczas, kiedy ma do tego odpowiednie środowisko. Takie kości znalezione w Krakowie, na stanowisku ulic Spadzista D i we wspomnianym już Dzierżysławiu (stanowisko 35) wskazują, że wykorzystywano je jako paliwo (Kozłowski, Sobczyk 1987; Sobczyk 1995; Ginter $\mathrm{i}$ in. 2002; Ginter i in. 2005).

W przypadku materiałów kamiennych uwagę zwraca fakt, że są to zazwyczaj pojedyncze otoczaki, które wcześniej poddane były działaniu ognia. Ciekawie prezentują się przepalone płytki kamienne ze stanowiska łowieckiego Klementowice-Kolonia na Płaskowyżu Nałęczowskim, ponieważ oprócz nich nie odnotowano innych pozostałości po działaniu ognia. Same płytki nie pozwalają też na interpretowanie ich jako elementu sztuki bądź paleniska (Kozłowski 1964; Kozłowski, Sobczyk 1987; Jastrzębski, Libera 1987; Sobczyk 1995; Ginter i in. 2002; Wiśniewski i in. 2012).

Ślady działania ognia odkryto na 29 stanowiskach otwartych oraz 8 jaskiniowych, co pozwala przypuszczać, że typ stanowiska nie miał wpływu na zachowanie się tego rodzaju pozostałości (tab. 2). Również pierwotna funkcja badanego stanowiska nie miała tu znaczenia, opisywane pozostałości odnotowano w obrębie 21 obozowisk, 7 pracowni krzemieniarskich, 3 obozowisk z pracownią krzemieniarską oraz 6 nieokreślonych stanowisk (tab. 3).

Ze względu na czas użytkowania danego miejsca można wyróżnić obozowiska długotrwałe/wielokrotnie zasiedlane (9), któtkoczasowe, ograniczające się tylko do kilkudniowego pobytu łowców paleolitycznych (9) oraz niesprecyzowane (6). W zestawieniu uwzględniono jedynie stanowiska badane wykopaliskowo (tab. 4), ponieważ tylko one dają możliwość uchwycenia tych zależności. W tym przypadku również domniemywa się, że czas pobytu nie miał znaczenia w zachowaniu i występowaniu śladów ognia. 
Najważniejszymi i najcenniejszymi pozostałościami po działaniu ognia są struktury ognisk. Tak interpretowane obiekty oraz ślady po nich, na przykład nagromadzenia rozmytych węgli drzewnych, zarejestrowano na 20 stanowiskach z ziem polskich (ryc. 2). Wśród elementów tworzących paleniska znalazły się między innymi: węgle drzewne (13), przepalony sedyment (3), przegrzane kamienie (4), przepalone kości (6), krzemienie (7), konstrukcje kamienne (2) (tab. 5).

Najbardziej czytelnymi strukturami są ogniska z przepalonym sedymentem. Odnotowano je na stanowisku kultury szeleckiej w Lubotyniu (stanowisko 11, pow. głubczycki, woj. opolskie), gdzie przepalony less zalegał w obrębie trzech obiektów nieruchomych. Na szczególną uwagę zasługuje bardzo dobrze zachowane ognisko nr 2, zagłębione w część klina mrozowego, którego wypełnisko składało się z pierwszej warstwy węgli drzewnych, niżej znajdował się przepalony sedyment, a pod nim zalegała druga warstewka węgielków. Pozostałe dwa paleniska, o średnicach nieprzekraczających $30 \mathrm{~cm}$, składały się z przepalonego lessu i rozmytych węgli drzewnych, jednak były bardziej zniszczone niż ognisko $\mathrm{nr} 2$. W obrębie tych struktur występowały nieliczne, przepalone krzemienie i pojedyncze kamienie ze śladami przegrzania, które jednak nie tworzyły żadnych regularnych układów (Połtowicz-Bobak i in. 2013). Kolejne stanowisko, w którego strukturach nieruchomych odnotowano przepalony sedyment to Brzoskwinia-Krzemionki (pow. krakowski, woj. małopolskie). To hipotetyczne (ze względu na znikome informacje) ognisko, zachowane $\mathrm{w}$ postaci przepalonego gruntu oraz akumulacji popiołu i węgli drzewnych, odkryto w obrębie pracowni krzemieniarskiej kultury magdaleńskiej (Ginter 1969; Sobczyk 1993). Ostatnie stanowisko z ziem polskich z zachowanym przepalonym lessem to wspomniany już Dzierżysław (stanowisko 35). W trzech obiektach, położonych w części spągowej wykopu zarejestrowano przepalony sedyment wraz z pozostałościami silnie przepalonych kości zwierzęcych, pyłu hematytowego, grudek ochry i okopconych bądź przepalonych płaskich kamieni (Ginter i in. 2002; Ginter i in. 2005). Pozostałości przepalonego sedymentu mogą jednoznacznie określić położenie paleolitycznego ogniska, jednak zachowują się one tylko w korzystnych warunkach (Taborin 1988; Terberger 1997), co może potwierdzać nieduża liczba stanowisk znanych z ziem polskich, gdzie odkryto tego rodzaju pozostałości.

Obok opisanych powyżej śladów warto wymienić paleniska z zachowanymi strukturami kamiennymi, które odkryto na dwóch stanowiskach kultury magdaleńskiej. W warstwie szóstej na stanowisku Krucza Skała (pow. zawierciański, woj. śląskie), natrafiono na skupiska węgli drzewnych, którym 


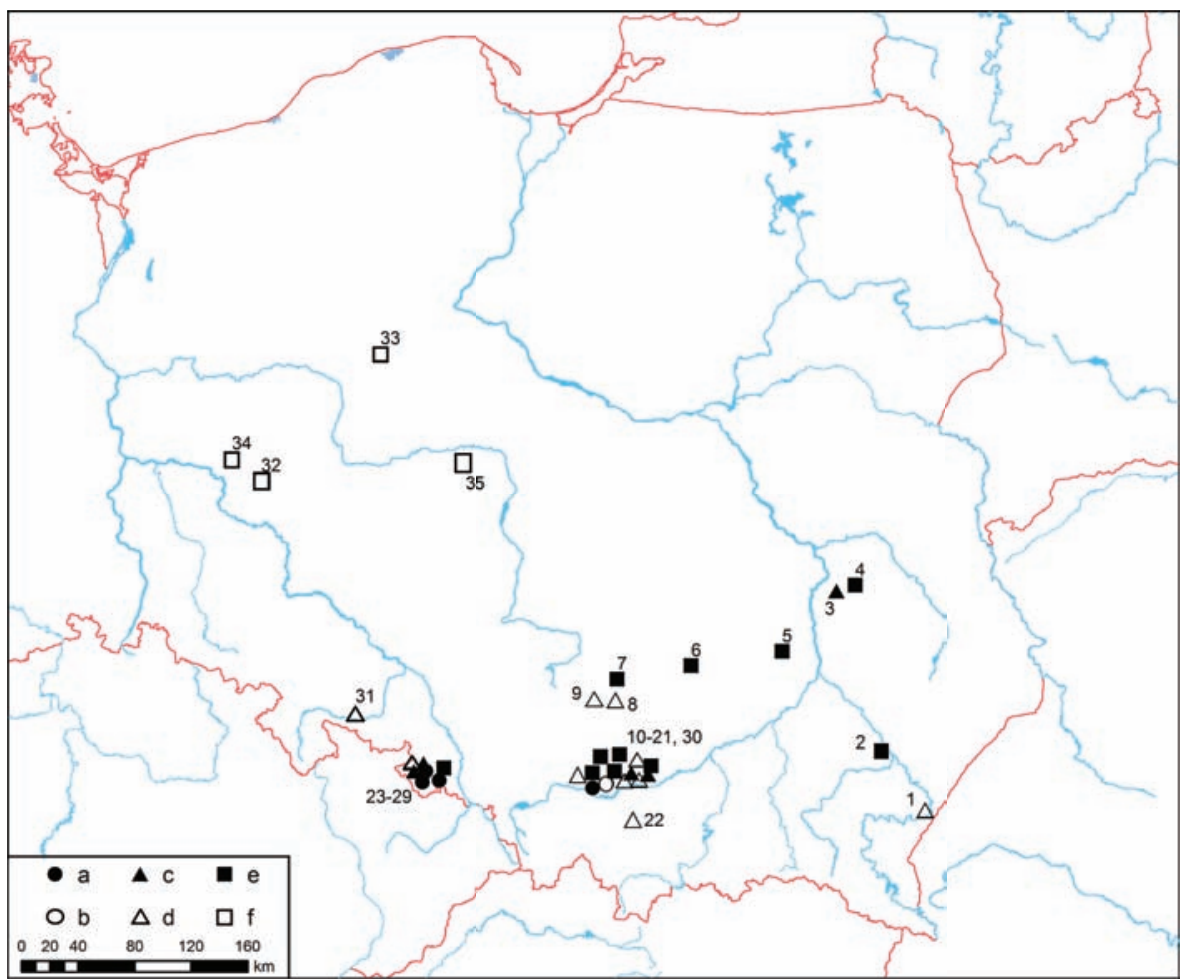

Ryc. 1. Stanowiska ze śladami działania ognia: 1 - Przemyśl (pow. przemyski, woj. podkarpackie); 2 - Wierzawice (pow. leżajski, woj. podkarpackie); 3 - Góra Puławska II (pow. puławski, woj. lubelskie); 4 - Klementowice-Kolonia (pow. puławski, woj. lubelskie); 5 - Ćmielów-Mały Gawroniec (pow. ostrowiecki, woj. świętokrzyskie); 6 - Mosty, stanowisko 13 (pow. kielecki, woj. świętokrzyskie); 7 - Schronisko Krucza Skała (pow. zawierciański, woj. śląskie); 8 - Jaskinia Deszczowa (pow. zawierciański, woj. śląskie); 9 - Jaskinia Dziadowa Skała (pow. zawierciański, woj. śląskie); 10 - Brzoskwinia-Krzemionki (pow. krakowski, woj. małopolskie); 11 - Wołowice (pow. krakowski, woj. małopolskie); 12 - Schronisko w Puchaczej Skale (pow. krakowski, woj. małopolskie); 13 - Jaskinia Zalas (pow. krakowski, woj. małopolskie); 14 - Jaskinia Nietoperzowa (pow. krakowski, woj. małopolskie); 15 - Jaskinia Mamutowa (pow. krakowski, woj. małopolskie); 16 - Kraków, ul. Spadzista A (woj. małopolskie); 17 - Kraków, ul. Spadzista B (woj. małopolskie); 18 - Kraków, ul. Spadzista (woj. małopolskie); 19 - Kraków, ul. Spadzista (woj. małopolskie); 20 - Kraków-Zwierzyniec I (woj. małopolskie); 21 - Przegorzały II (pow. krakowski, woj. małopolskie); 22 - Targowisko (pow. wielicki, woj. małopolskie); 23 - Pietraszyn (pow. raciborski, woj. śląskie); 24 - Pietrowice Wielkie (pow. raciborski, woj. śląskie); 25 - Lubotyń, stanowisko 1/10 (pow. głubczycki, woj. opolskie); 26 - Lubotyń, stanowisko 11 (pow. głubczycki, woj. opolskie); 27 - Dzierżysław, stanowisko 1 (pow. głubczycki, woj. opolskie); 28 - Dzierżysław, 
stanowisko 8 (pow. głubczycki, woj. opolskie); 29 - Dzierżysław, stanowisko 35 (pow. głubczycki, woj. opolskie); 30 - Broniszowice (pow. nyski, woj. opolskie); 31 - Wójcice (pow. nyski, woj. opolskie); 32 - Olbrachcice (pow. wschowski, woj. lubuskie); 33 - Mirkowice (pow. wągrowiecki, woj. wielkopolskie); 34 - Liny (pow. zielonogórski, woj. lubuskie); 35 - Krągola (pow. koniński, woj. wielkopolskie); 36 - Jaskinia Maszycka (pow. krakowski, woj. małopolskie); 37 - Wilczyce (pow. sandomierski, woj. świętokrzyskie). a - kultura szelecka; b - kultura jerzmanowicka; c - kultura oryniacka; d - kultura grawecka; e - kultura magdaleńska; f - kultura hamburska (rys. K. Szpunar)

Fig. 1. Sites with traces of fire: 1 - Przemyśl (Przemyśl County, Subcarpathian Voivodeship); 2 - Wierzawice (Leżajsk County, Subcarpathian Voivodeship); 3 - Góra Pułwaska II (Puławy County, Lublin Voivodeship); 4 - Klementowice-Kolonia (Puławy County, Lublin Voivodeship); 5 - ĆmielówMały Gawroniec (Ostrowiec County, Holy Cross Voivodeship); 6 - Mosty, site 13 (Kielce County, Holy Cross Voivodeship); 7 - Krucza Skała Schleter (Zawiercie County, Silesian Voivodeship); 8 - Deszczowa Cave (Zawiercie County, Silesian Voivodeship); 9 - Dziadowa Skała Cave (Zawiercie County, Silesian Voivodeship); 10 - Brzoskwinia-Krzemionki (Kraków County, Lesser Poland Voivodeship); 11 - Wołowice (Kraków County, Lesser Poland Voivodeship); 12 - Puchacza Skała Schleter (Kraków County, Lesser Poland Voivodeship); 13 - Zalas Cave (Kraków County, Lesser Poland Voivodeship); 14 - Nietoperzowa Cave (Kraków County, Lesser Poland Voivodeship); 15 - Mamutowa Cave (Kraków County, Lesser Poland Voivodeship); 16 - Kraków, Spadzista A street (Lesser Poland Voivodeship); 17 - Kraków, Spadzista B street (Lesser Poland Voivodeship); 18 - Kraków, Spadzista C street (Lesser Poland Voivodeship); 19 - Kraków, Spadzista D street (Lesser Poland Voivodeship); 20 - Kraków-Zwierzyniec I (Lesser Poland Voivodeship); 21 - Przegorzały II (Kraków County, Lesser Poland Voivodeship); 22 - Targowisko (Wieliczka County, Lesser Poland Voivodeship); 23 - Pietraszyn (Racibórz County, Silesian Voivodeship); 24 - Pietrowice Wielkie (Racibórz County, Silesian Voivodeship); 25 - Lubotyń, site 1/10 (Głubczyce County, Opole Voivodeship); 26 - Lubotyń, site 11(Głubczyce County, Opole Voivodeship); 27 - Dzierżysław, site 1 (Głubczyce County, Opole Voivodeship); 28 - Dzierżysław, site 8 (Głubczyce County, Opole Voivodeship); 29 - Dzierżysław, site 35 (Głubczyce County, Opole Voivodeship); 30 - Broniszowice (Nysa County, Opole Voivodeship); 31 - Wójcice (Nysa County, Opole Voivodeship); 32 - Olbrachcice (Wschowa County, Lubusz Voivodeship); 33 - Mirkowice (Wągrowiec County, Greater Poland Voivodeship); 34 - Liny (Zielona Góra County, Lubusz Voivodeship); 35 - Krągola (Konin County, Greater Poland Voivodeship); 36 - Maszycka Cave (Kraków County, Lesser Poland Voivodeship); 37 - Wilczyce (Sandomierz County, Holy Cross Voivodeship). a - Szeletian; b - Jerzmanowician; c - Aurignacian; d - Gravettian; e - Magdalenian; f-Hamburgian. Sites (drawn by K. Szpunar) 


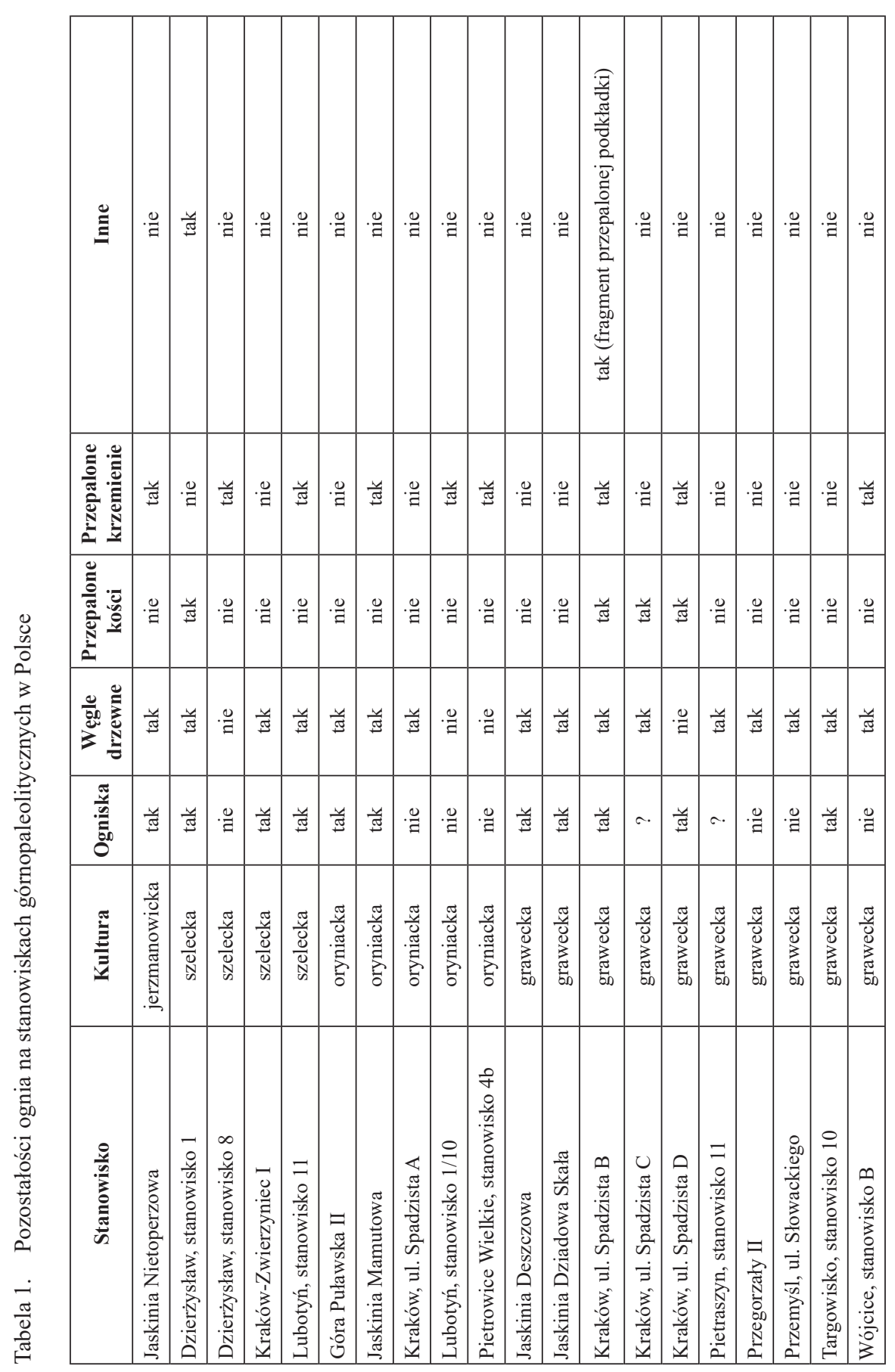




\begin{tabular}{|c|c|c|c|c|c|c|c|c|c|c|c|c|c|c|c|c|c|c|}
\hline$\stackrel{\Xi}{\Xi}$ & $\cong$ & $\cong$ &.$\oslash$ & $\cong$ & $\cong$ & $\stackrel{\varrho}{\rightrightarrows}$ & 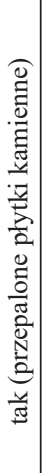 & $\stackrel{\varrho}{\exists}$ & $\cong$ & $\stackrel{\varrho}{\exists}$ &.$\cong$ & 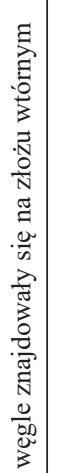 & $\stackrel{\varrho}{\Xi}$ & $\cong$ & $\stackrel{\varrho}{\exists}$ & . & $\cong$ & $N$ \\
\hline 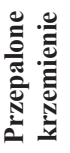 & 芩 & 芩 & $\cong$ & ज्ञ & 芩 & 苛 &.$\cong$ & 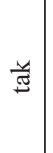 &.$\cong$ & 首 & ๘ & $\stackrel{\mathscr{\Xi}}{\exists}$ & 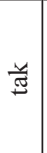 & ज्ञ & 光 & $\cong$ & 芩 & సิ \\
\hline 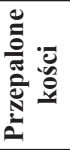 & .्ֶ & .ֶ) & $\stackrel{\varrho}{\exists}$ & छै &.$\cong$ & $\stackrel{\varrho}{\rightrightarrows}$ &.$\cong$ & $\stackrel{\Xi}{\exists}$ & $\stackrel{\mathscr{\Xi}}{\exists}$ & $\stackrel{\varrho}{\Xi}$ & $\cong$ & $\stackrel{\mathscr{Z}}{\exists}$ & $\stackrel{\varrho}{\Xi}$ & $\stackrel{\varrho}{\Xi}$ & $\cong$ & 芩 & Ш & $r$ \\
\hline 党 & .ֶ & छै & 芭 & 芩 &.$\cong$ & 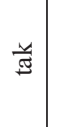 &.$\cong$ & 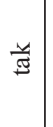 & 芩 & ज्ञ & 㐘 & छै & छै &.$\cong$ & $\cong$ &.$\cong$ & 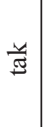 & $\grave{\sim}$ \\
\hline 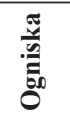 &.$\cong$ & 总 & $\cong$ & 壱 & $\stackrel{\cong}{\Xi}$ & 夰 &.$\cong$ & 光 & 壱 & 总 & 壱 & $\cong$ &.$\cong$ &.$\cong$ & 总 & ङ & $\stackrel{\cong}{\Xi}$ & ㄱ. \\
\hline 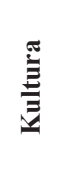 & 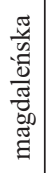 & 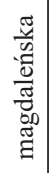 & 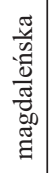 & 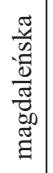 & 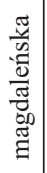 & 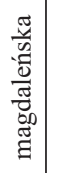 & 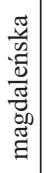 & 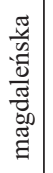 & 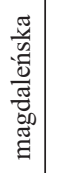 & 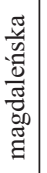 & 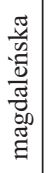 & 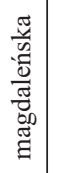 & 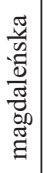 & 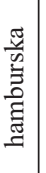 & 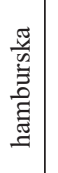 & 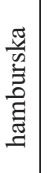 & 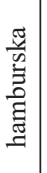 & \\
\hline 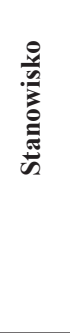 & 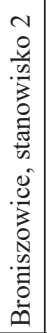 & 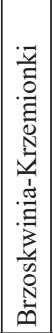 & 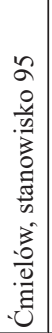 & 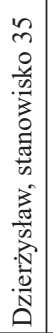 & 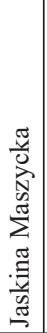 & 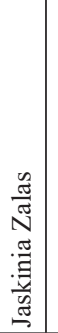 & 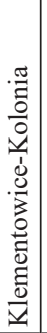 & 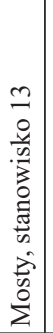 & 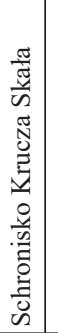 & 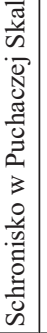 & 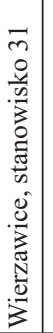 & 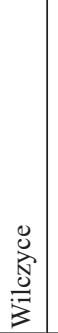 & 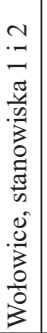 & 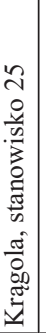 & 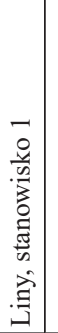 & 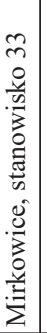 & 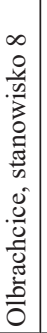 & 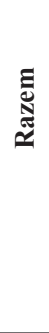 \\
\hline
\end{tabular}


Tabela 2. Podział stanowisk z zachowanymi śladami działania ognia ze względu na ich typ

\begin{tabular}{|c|c|c|}
\hline \multirow{2}{*}{ Stanowisko } & \multicolumn{2}{|c|}{ Typ stanowiska } \\
\hline & otwarte & jaskiniowe \\
\hline Jaskinia Nietoperzowa & & tak \\
\hline Dzierżysław, stanowisko 1 & tak & \\
\hline Dzierżysław, stanowisko 8 & tak & \\
\hline Kraków-Zwierzyniec I & tak & \\
\hline Lubotyń, stanowisko 11 & tak & \\
\hline Góra Puławska II & tak & \\
\hline Jaskinia Mamutowa & & tak \\
\hline Kraków, ul. Spadzista A & tak & \\
\hline Lubotyń, stanowisko 1/10 & tak & \\
\hline Pietrowice Wielkie, stanowisko 4b & tak & \\
\hline Jaskinia Deszczowa & & tak \\
\hline Jaskinia Dziadowa Skała & & tak \\
\hline Kraków, ul. Spadzista B & tak & \\
\hline Kraków, ul. Spadzista C & tak & \\
\hline Kraków, ul. Spadzista D & tak & \\
\hline Pietraszyn, stanowisko 11 & tak & \\
\hline Przegorzały II & tak & \\
\hline Przemyśl, ul. Słowackiego & tak & \\
\hline Targowisko, stanowisko 10 & tak & \\
\hline Wójcice, stanowisko B & tak & \\
\hline Broniszowice, stanowisko 2 & tak & \\
\hline Brzoskwinia-Krzemionki & tak & \\
\hline Ćmielów, stanowisko 95 & tak & \\
\hline Dzierżysław, stanowisko 35 & tak & \\
\hline Jaskinia Maszycka & & tak \\
\hline Jaskinia Zalas & & tak \\
\hline Klementowice-Kolonia & tak & \\
\hline Mosty, stanowisko 13 & tak & \\
\hline Schronisko Krucza Skała & & tak \\
\hline Schronisko w Puchaczej Skale & & tak \\
\hline Wierzawice, stanowisko 31 & tak & \\
\hline Wilczyce & tak & \\
\hline Wołowice, stanowiska 1 i 2 & tak & \\
\hline Krągola, stanowisko 25 & tak & \\
\hline Liny, stanowisko 1 & tak & \\
\hline Mirkowice, stanowisko 33 & tak & \\
\hline Olbrachcice & tak & \\
\hline Razem & 29 & 8 \\
\hline
\end{tabular}


Tabela 3. Podział stanowisk ze śladami działania ognia ze względu na ich funkcję

\begin{tabular}{|c|c|c|c|c|}
\hline \multirow[b]{2}{*}{ Stanowisko } & \multicolumn{4}{|c|}{ Funkcja stanowiska } \\
\hline & $\begin{array}{l}\text { obozo- } \\
\text { wisko }\end{array}$ & $\begin{array}{c}\text { pracownia } \\
\text { krzemieniarska }\end{array}$ & $\begin{array}{c}\text { obozowisko } \\
\text { z pracownią } \\
\text { krzemieniarską }\end{array}$ & nieokreślona \\
\hline Jaskinia Nietoperzowa & tak & & & \\
\hline Dzierżysław, stanowisko 1 & tak & & & \\
\hline Dzierżysław, stanowisko 8 & & tak & & \\
\hline Kraków-Zwierzyniec I & tak & & & \\
\hline Lubotyń, stanowisko 11 & tak & & & \\
\hline Góra Puławska II & & & tak & \\
\hline Jaskinia Mamutowa & tak & & & \\
\hline Kraków, ul. Spadzista A & & & & tak \\
\hline Lubotyń, stanowisko 1/10 & & & & tak \\
\hline $\begin{array}{l}\text { Pietrowice Wielkie, } \\
\text { stanowisko } 4 \mathrm{~b}\end{array}$ & & tak & & \\
\hline Jaskinia Deszczowa & tak & & & \\
\hline Jaskinia Dziadowa Skała & & & & tak \\
\hline Kraków, ul. Spadzista B & & & tak & \\
\hline Kraków, ul. Spadzista C & tak & & & \\
\hline Kraków, Spadzista D & tak & & & \\
\hline Pietraszyn, stanowisko 11 & & tak & & \\
\hline Przegorzały II & tak & & & \\
\hline Przemyśl, ul. Słowackiego & & & & tak \\
\hline Targowisko, stanowisko 10 & tak & & & \\
\hline Wójcice, stanowisko B & & & tak & \\
\hline Broniszowice, stanowisko 2 & & & & tak \\
\hline Brzoskwinia-Krzemionki & & tak & & \\
\hline Ćmielów, stanowisko 95 & tak & & & \\
\hline Dzierżysław, stanowisko 35 & tak & & & \\
\hline Jaskinia Maszycka & tak & & & \\
\hline Jaskinia Zalas & & tak & & \\
\hline Klementowice-Kolonia & tak & & & \\
\hline Mosty, stanowisko 13 & tak & & & \\
\hline Schronisko Krucza Skała & tak & & & \\
\hline Schronisko w Puchaczej Skale & & & & tak \\
\hline Wierzawice, stanowisko 31 & tak & & & \\
\hline Wilczyce & tak & & & \\
\hline Wołowice, stanowiska 1 i 2 & & tak & & \\
\hline Liny, stanowisko 1 & tak & & & \\
\hline Mirkowice, stanowisko 33 & tak & & & \\
\hline Krągola, stanowisko 25 & tak & & & \\
\hline Olbrachcice, stanowisko 8 & & tak & & \\
\hline Razem & 21 & 7 & 3 & 6 \\
\hline
\end{tabular}


Tabela 4. Podział obozowisk ze śladami działania ognia ze względu na czas ich użytkowania

\begin{tabular}{|c|c|c|c|}
\hline Stanowisko & \multicolumn{2}{|c|}{$\begin{array}{c}\text { Obozowisko } \\
\text { krótkotrwale }\end{array}$} & nieokreślone \\
\hline Jaskinia Nietoperzowa & wielosezonowe & tak & \\
\hline Dzierżysław, stanowisko 1 & tak & & \\
\hline Kraków-Zwierzyniec I & tak & & \\
\hline Lubotyń, stanowisko 11 & tak & & tak \\
\hline Góra Puławska II & & & \\
\hline Jaskinia Mamutowa & tak & & \\
\hline Jaskinia Deszczowa & & tak & \\
\hline Kraków, ul. Spadzista B & & & \\
\hline Kraków, ul. Spadzista C & & tak & \\
\hline Kraków, ul. Spadzista D & tak & & tak \\
\hline Przegorzały II & & tak & \\
\hline Targowisko, stanowisko 10 & & & \\
\hline Ćmielów & & tak & \\
\hline Dzierżysław, stanowisko 35 & tak & tak & \\
\hline Jaskinia Maszycka & tak & tak & \\
\hline Klementowice-Kolonia & & & \\
\hline Mosty, stanowisko 13 & & & tak \\
\hline Schronisko Krucza Skała & & & \\
\hline Wierzawice, stanowisko 31 & & & \\
\hline Wilczyce & tak & & \\
\hline Krągola, stanowisko 25 & & & \\
\hline Liny, stanowisko 1 & & & \\
\hline Mosty, stanowisko 33 & & & \\
\hline Razem & & & \\
\hline
\end{tabular}

towarzyszyły pozostałości poroży reniferów i kilka wyrobów krzemiennych. Koncentracje węgla drzewnego zalegały obok leżących płasko lub wbitych pionowo w podłoże kamieni, co interpretowane jest jako rodzaj paleniska (Cyrek 1994; 2002; 2010). Z kolei w Wierzawicach (pow. leżajski, woj. podkarpackie) odsłonięto zachowaną w całości strukturę kamienną o średnicy 20-25 cm utworzoną z otoczaków i płytek piaskowca ze śladami przegrzania i intencjonalnej działalności; towarzyszyły jej liczne skupienia tylczaków. Obiekt, jak i jego rozmieszczenie w obrębie obozowiska mają pewne analogie wśród stanowisk z Francji - Pincevent i Etiolles, Szwajcarii - Monruz, Chmpréveryes i Niemiec - Gönnersdorf (Julien 1987; Julien 1988; Olive 1988; Taborin 1988; Terberger 1997; Bobak i in. 2010; Leesch i in. 2010).

Układ ognisk w kontekście rozplanowania przestrzennego może odgrywać znaczącą rolę w poznaniu życia górnopaleolitycznych łowców. Tak więc, jedno palenisko mogło stanowić centrum obozowiska, tak jak w przypadku stanowiska w Wierzawicach, będącego typowym przykładem kilkudniowe- 
go obozowiska. Aktywność łowców skupiała się tutaj wokół ogniska, przy którym prawdopodobnie wytwarzano broń łowiecką, co sugeruje kilka koncentracji zbrojników w bezpośrednim sąsiedztwie paleniska (ryc. 3). Hipotezę tę dodatkowo mogą potwierdzać analogiczne rozplanowania przestrzeni na wspomnianych już stanowiskach w Monruz, Chmpréveryes, Gönnersdorf, Pincevent (Julien 1987; Olive 1988; Terberger 1997; Bobak i in. 2010; Leesch i in. 2010).

Podobne rozplanowania przestrzeni zauważalne są w Jaskini Deszczowej na Wyżynie Częstochowskiej i na wspomnianym już stanowisku w Brzoskwini-Krzemionkach. W jaskini odkryto pozostałości epigraweckiego obozowiska, z ogniskiem zachowanym w postaci nagromadzenia węgli i przepalonych kamieni, wokół którego zalegały liczne wyroby krzemienne i przedmioty sztuki (Cyrek i in. 2000). W pracowni krzemieniarskiej odkrytej w Brzoskwini-Krzemionkach strefa wokół paleniska mogła być związana z wytwarzaniem narzędzi, jednak niedostateczna ilość danych ogranicza szczegółowsze analizy jego kontekstu względem całego stanowiska (Ginter 1969; Sobczyk 1993).

Inne stanowiska $\mathrm{z}$ zachowanym tylko jednym obiektem interpretowanym jako ognisko znane są z Krakowa-Zwierzyńca (Kozłowski 1960; Chmielewski 1975; Kozłowski, Kozłowski 1977), znajdującej się blisko Krakowa Jaskini Zalas (Bocheński i in. 1985) i Schroniska Krucza Skała położonego w Skałach Kroczyckich (Cyrek 1994), jednakże zaburzenia soliflukcyjne, skomplikowane układy przestrzenne oraz ubogi inwentarz znacznie ograniczają możliwości interpretacyjne.

Warto jeszcze wymienić miejsca, gdzie jedno palenisko znajdowało się w sąsiedztwie koncentracji krzemieni. Układ taki zarejestrowano w Dzierżysławiu (stanowisko 1, pow. głubczycki, woj. opolskie) w szeleckim poziomie kulturowym. W południowej części wykopu rozdrobnione węgle drzewne znajdowały się nieopodal skupienia artefaktów krzemiennych (Kozłowski 1964; Wiśniewski 2006). Zbliżoną sytuację zaobserwowano na stanowiskach kultury hamburskiej w Linach (pow. zielonogórski, woj. lubuskie) i Mirkowicach (pow. wągrowiecki, woj. wielkopolskie). Na pierwszym z nich ognisko utworzone z nagromadzenia przepalonych krzemieni mieściło się w obrębie koncentracji artefaktów o wymiarach $13 \times 5$ m (Kobusiewicz 1975), natomiast na drugim składało się ono z narzędzi krzemiennych i kilku przepalonych kości zwierzęcych, co uchwycono w jednej z koncentracji krzemieni (nr 1) (Kabaciński i in. 1999). W przypadku tych obozowisk, w obrębie których odnotowano tylko jedno palenisko, można przypuszczać, że właśnie wokół niego toczyło się życie ówczesnych ludzi. Jednak na większości stanowisk 


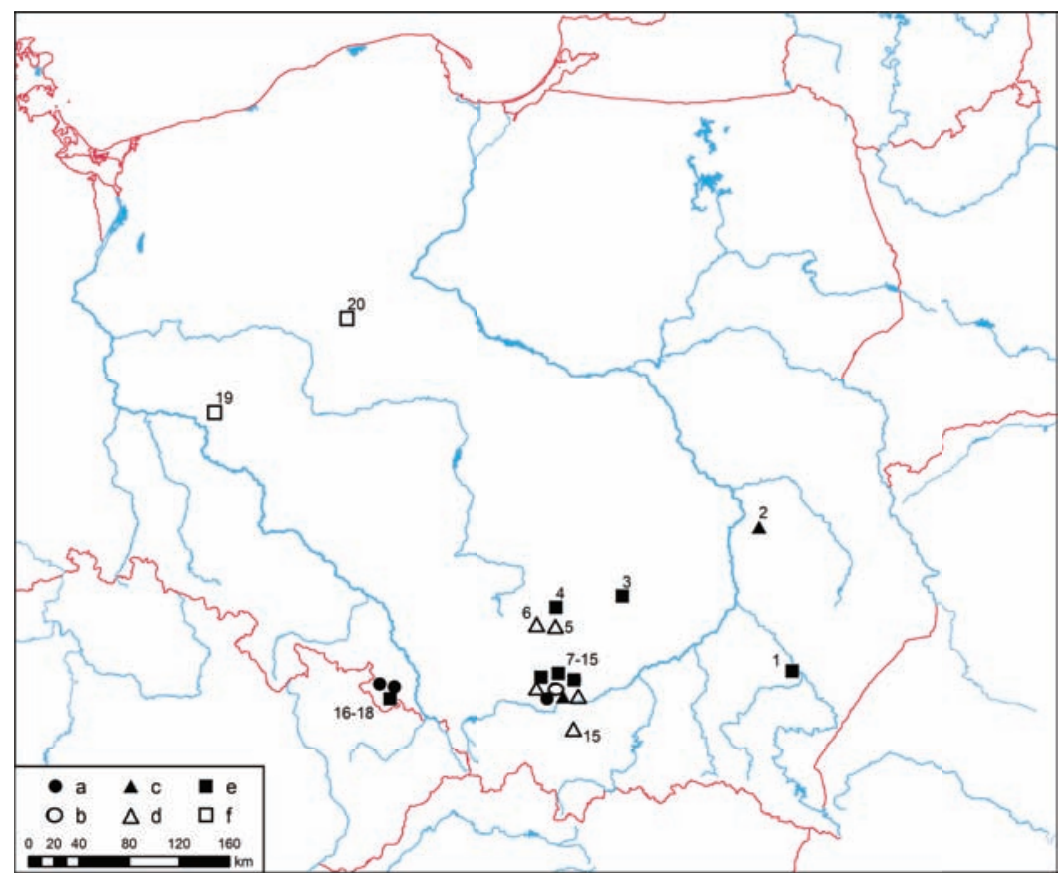

Ryc. 2. Stanowiska z zachowanymi ogniskami: 1 - Wierzawice (pow. leżajski, woj. podkarpackie); 2 - Góra Puławska II (pow. puławski, woj. lubelskie); 3 - Mosty, stanowisko 13 (pow. kielecki, woj. świętokrzyskie); 4 - Jaskinia Krucza Skała (pow. zawierciański, woj. śląskie); 5 - Jaskinia Deszczowa (pow. zawierciański, woj. śląskie); 6 - Jaskinia Dziadowa Skała (pow. zawierciański, woj. śląskie); 7 - Brzoskwinia-Krzemionki (pow. krakowski, woj. małopolskie); 8 - Jaskinia w Puchaczej Skale (pow. krakowski, woj. małopolskie); 9 - Jaskinia Zalas (pow. krakowski, woj. małopolskie); 10 - Jaskinia Nietoperzowa (pow. krakowski, woj. małopolskie); 11 - Jaskinia Mamutowa (pow. krakowski, woj. małopolskie); 12 - Kraków, ul. Spadzista B (woj. małopolskie); 13 - Kraków, ul. Spadzista D (woj. małopolskie); 14 - Kraków-Zwierzyniec I (woj. małopolskie); 15 - Targowisko (pow. wielicki, woj. małopolskie); 16 - Lubotyń, stanowisko 11 (pow. głubczycki, woj. opolskie); 17 - Dzierżysław, stanowisko 1 (pow. głubczycki, woj. opolskie); 18 - Dzierżysław, stanowisko 35 (pow. głubczycki, woj. opolskie); 19 - Liny (pow. zielonogórski, woj. lubuskie); 20 - Mirkowice (pow. wągrowiecki, woj. wielkopolskie). a - kultura szelecka; b - kultura jerzmanowicka; c - kultura oryniacka; d - kultura grawecka; e - kultura magdaleńska; f - kultura hamburska (rys. K. Szpunar)

Fig. 2. Sites with hearth remains: 1 - Wierzawice (Leżajsk County, Subcarpathian Voivodeship); 2 - Góra Puławska II (Puławy County, Lublin Voivodeship); 3 - Mosty, site 13 (Kielce County, Holy Cross Voivodeship); 4 - Krucza Skała Schleter (Zawiercie County, Silesian Voivodeship); 5 - Deszczowa Cave (Zawiercie County, Silesian Voivodeship); 6 - Dziadowa Skała Cave (Zawiercie County, Silesian Voivodeship); 7 - Brzoskwinia-Krzemionki (Kraków County, Lesser Poland Voivodeship); 8 - Puchacza Skała Schleter (Kraków County, Lesser Poland Voivodeship); 9 - Zalas Cave (Kraków County, Lesser Poland Voivodeship); 10 - Nietoperzowa Cave (Kraków County, Lesser Poland Voivodeship); 11 - Mamutowa Cave (Kraków County, Lesser 
Poland Voivodeship); 12 - Kraków, Spadzista B street (Kraków County, Lesser Poland Voivodeship); 13 - Kraków, Spadzista D street (Kraków County, Lesser Poland Voivodeship); 14-Kraków-Zwierzyniec I(LesserPoland Voivodeship); 15-Targowisko (Wieliczka County, Lesser Poland Voivodeship); 16-Lubotyń, site 11 (Głubczyce County, Opole Voivodeship); 17 - Dzierżysław, site 1 (Głubczyce County, Opole Voivodeship); 18 - Dzierżysław, site 35 (Głubczyce County, Opole Voivodeship); 19 - Liny (Zielona Góra County, Lubusz Voivodeship); 20 - Mirkowice (Wągrowiec County, Greater Poland Voivodeship). a - Szeletian; b - Jerzmanowician; c - Aurignacian; d-Gravettian; e - Magdalenian; f - Hamburgian (drawn by K. Szpunar)

Tabela 5. Zestawienie materiałów źródłowych interpretowanych jako ogniska

\begin{tabular}{|c|c|c|c|c|c|c|c|}
\hline Stanowisko & 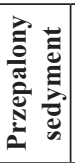 & 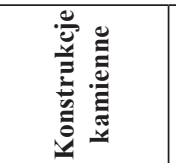 & 党 & $\begin{array}{l}\ddot{e} \\
\ddot{\theta} \\
\ddot{\theta}\end{array}$ & ב⿱艹 & 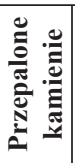 & $\stackrel{巳}{\Xi}$ \\
\hline Jaskinia Nietoperzowa & nie & nie & nie & tak & tak & nie & \\
\hline Dzierżysław, stanowisko 1 & nie & nie & tak & nie & nie & nie & \\
\hline Kraków-Zwierzyniec I & nie & nie & tak & nie & nie & nie & materiał organiczny \\
\hline Lubotyń, stanowisko 11 & tak & nie & tak & nie & tak & nie & \\
\hline Góra Puławska II & nie & nie & tak & nie & nie & nie & $\begin{array}{c}\text { krzemienie i kości } \\
\text { koncentrowały się wokó } \\
\text { ognisk }\end{array}$ \\
\hline Jaskinia Mamutowa & nie & nie & tak & nie & nie & nie & \\
\hline Jaskinia Deszczowa & nie & nie & tak & nie & nie & tak & \\
\hline Jaskinia Dziadowa Skała & nie & nie & tak & nie & nie & nie & \\
\hline Kraków, ul. Spadzista B & nie & nie & tak & tak & nie & nie & \\
\hline Kraków, ul. Spadzista D & nie & nie & nie & tak & nie & nie & $\begin{array}{c}\text { w ogniskach występował } \\
\text { druzgot }\end{array}$ \\
\hline Targowisko, stanowisko 10 & nie & nie & tak & nie & tak & nie & $\begin{array}{c}\text { koncentryczne układy } \\
\text { krzemieni }\end{array}$ \\
\hline Brzoskwinia-Krzemionki & tak & nie & tak & nie & nie & nie & popiół i przepalona glina \\
\hline Dzierżysław, stanowisko 35 & tak & nie & nie & tak & nie & tak & \\
\hline Jaskinia Zalas & nie & nie & tak & nie & nie & nie & \\
\hline Mosty, stanowisko 13 & nie & nie & tak & nie & nie & tak & $\begin{array}{c}\text { jama pyłu iluwialnego } \\
\text { z przegrzanymi } \\
\text { kamieniami }\end{array}$ \\
\hline Schronisko Krucza Skała & nie & $\begin{array}{c}\text { tak (kamienie, } \\
\text { leżące płasko } \\
\text { lub wbite } \\
\text { pionowo) }\end{array}$ & tak & tak & tak & nie & \\
\hline $\begin{array}{c}\text { Schronisko } \\
\text { w Puchaczej Skale }\end{array}$ & nie & nie & nie & nie & nie & nie & $\begin{array}{l}\text { brak dokładnych in- } \\
\text { formacji o charakterze } \\
\text { pozostałości ognisk }\end{array}$ \\
\hline Wierzawice, stanowisko 31 & nie & tak & nie & nie & tak & nie & \\
\hline Liny, stanowisko 1 & nie & nie & nie & nie & tak & nie & \\
\hline Mirkowice, stanowisko 33 & nie & nie & nie & tak & tak & tak & \\
\hline Razem & 3 & 2 & 13 & 6 & 7 & 4 & 6 \\
\hline
\end{tabular}




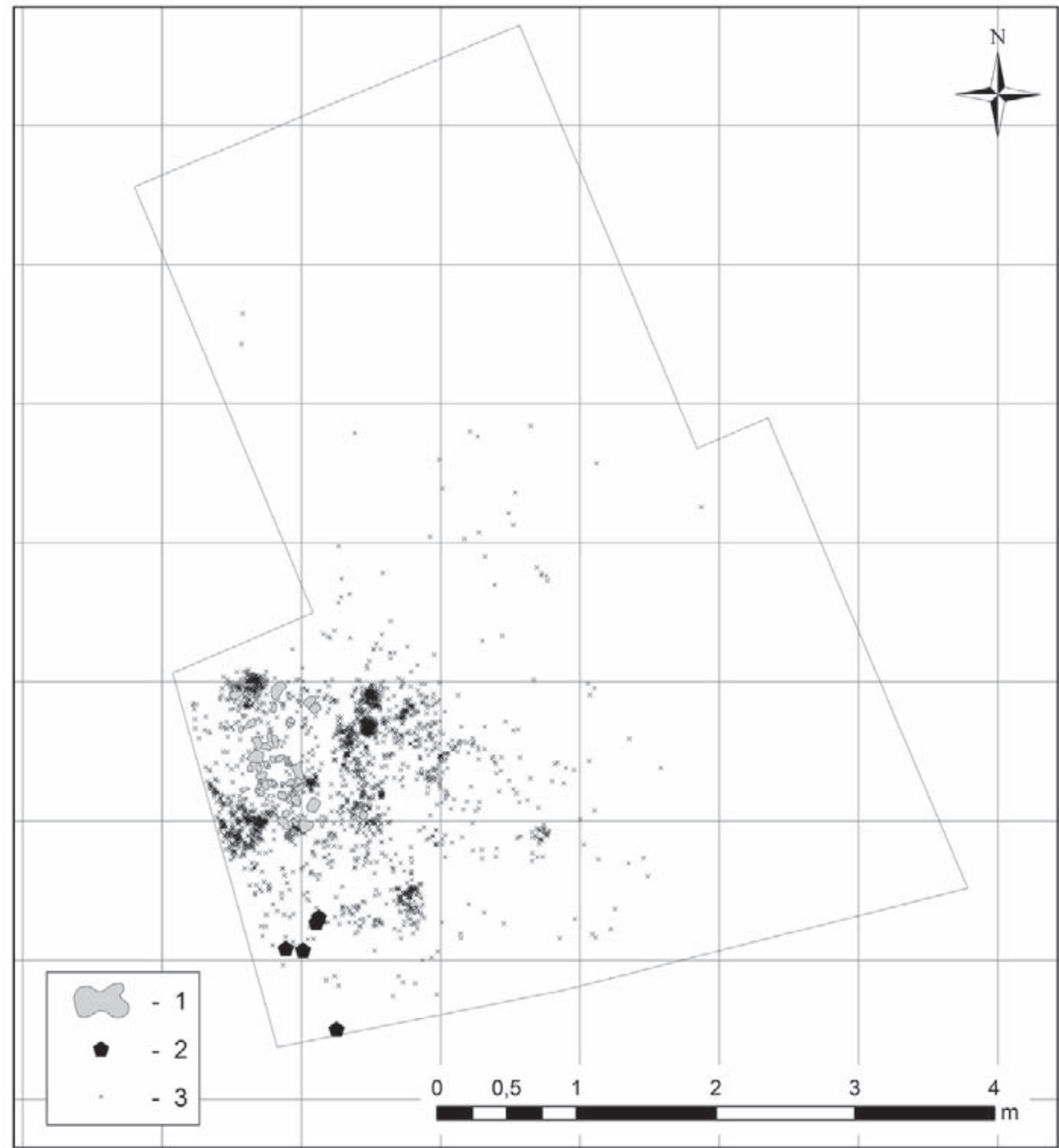

Ryc. 3. Wierzawice, stanowisko 31. Planigrafia znalezisk: 1 - kamienie tworzące ognisko, 2 - hematyt, 3 - krzemienie (wg Bobak i in. 2010)

Fig. 3. Wierzawice, site 31 . The finds' planigraphy: 1 - stones forming the hearth, 2 - hematite, 3 - flints (after Bobak et al. 2010)

(np. kultury hamburskiej) układy przestrzenne są mało czytelne, dlatego też niemożliwe jest formułowanie bliższych wniosków.

$\mathrm{Na}$ stanowiskach górnopaleolitycznych odnotowano także pozostałości po kilku ogniskach. Struktury takie zachowały się na stanowiskach jaskiniowych oraz otwartych. W przypadku jaskiń Nietoperzowej i Mamutowej, położonych w południowej część Jury Krakowsko-Częstochowskiej, uchwycono linię ognisk w postaci nagromadzenia węgli drzewnych (Kozłowski 1960; Kowalski 1967; Chmielewski 1975; Kozłowski, Kozłowski 1977). Podobna 


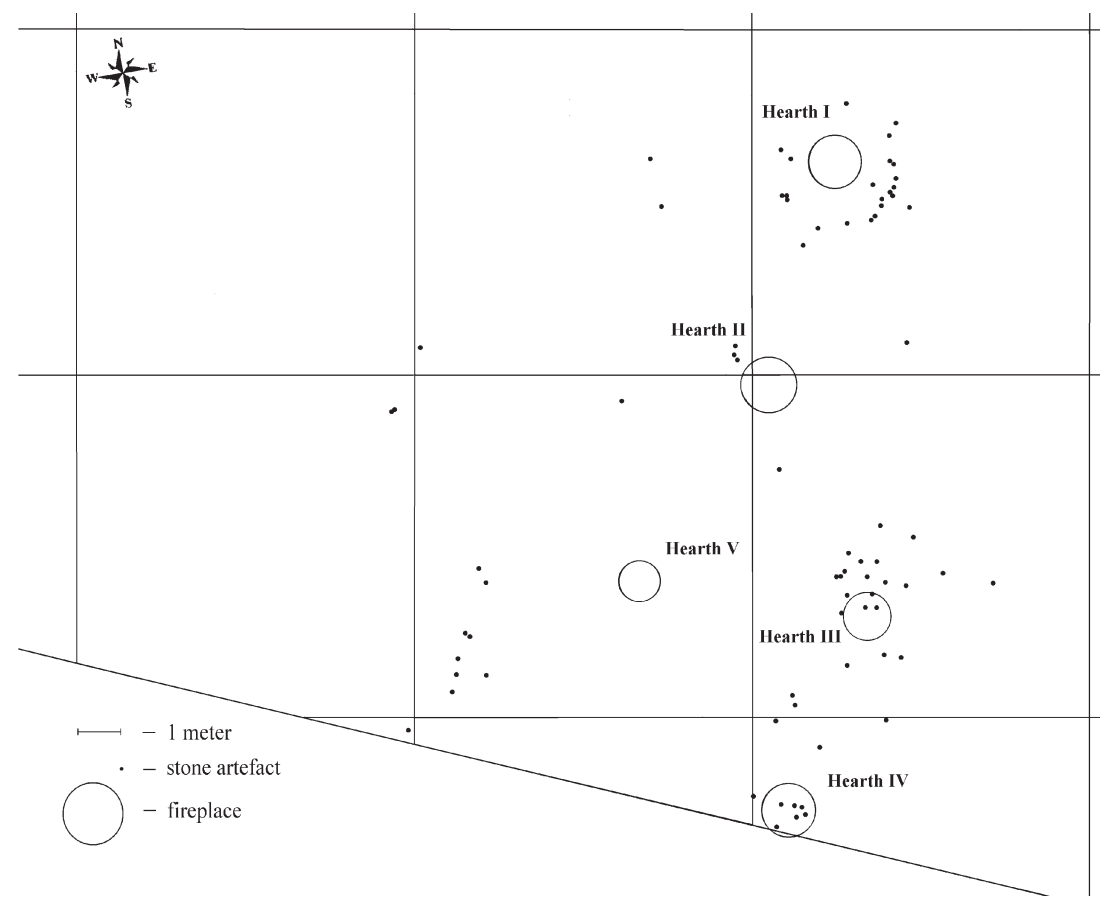

Ryc. 4. Targowisko, stanowisko 10. Planigrafia układu ognisk i narzędzi krzemiennych (wg Wilczyński 2009)

Fig. 4. Targowisko, site 10. Spatial distribution of the hearths and tools (after Wilczyński 2009)

sytuacja miała miejsce w poziomie graweckim na stanowisku Dziadowa Skała położonym w środkowej części Jury Krakowsko-Częstochowskiej. Odsłonięto tam dwa skupienia węgli drzewnych wraz rozmytą warstwą popiołów, które zinterpretowano jako paleniska (Chmielewski 1958). Zdaniem badaczy powyższe układy i rozmieszczenia ognisk na tych stanowiskach jaskiniowych, mogły być związane z polowaniami na zwierzęta jaskiniowe (Chmielewski 1958; 1975; Flas 2008).

Ciekawie prezentują się też stanowiska otwarte na przykład we wspomnianym już Lubotyniu (stanowisko 11). Zachowały się tam pozostałości po sześciu(?) ogniskach oraz rozmyte i rozproszone na całej powierzchni stanowiska węgle drzewne, być może związane ze strefą wyprzątania materiału z ogniska. Sugerować to mogą położone blisko siebie trzy, cztery zaciemnienia o średnicach około $30 \mathrm{~cm}$, których stan zachowania wskazuje raczej, że są one rozmytym śladem po jednym dużym ognisku lub właśnie miejscem, gdzie usuwano odpadki. Analogiczne rozmieszczenie, podobnych pod względem morfologicznym struktur nieruchomych, zaobserwowano na stanowisku 
kultury szeleckiej w Vedrowicach na Morawach (Taborin 1988; Valoch 1993; Terberger 1997; Połtowicz-Bobak i in. 2013). Warto też zwrócić uwagę na układ pięciu obiektów odsłonięty na epigraweckim stanowisku Targowisko (pow. wielicki, woj. małopolskie) (ryc. 4). W centrum tego użytkowanego przez krótki czas obozowiska znajdowało się bardzo dobrze zachowane palenisko (nr I) o średnicy $5 \mathrm{~m}$. Kolejne dwa paleniska - nr III i nr IV - były znacznie gorzej zachowane, natomiast $\mathrm{nr}$ II i nr V występowały tylko w postaci węgli drzewnych (Wilczyński 2009). Opisany układ pozwala przypuszczać, że istniały tu strefy wyprzątania odpadków z najlepiej zachowanego paleniska (nr I) na inne miejsca (ogniska nr II, nr III, nr IV, nr V), lub też może sugerować, że ognisko nr I było główną bądź ostatnią strefą aktywności ludności epigraweckiej zamieszkującej ten teren (Schmieder 1988; Wilczyński 2009).

Inaczej rysuje się sytuacja w kompleksie stanowisk kultury graweckiej z ulicy Spadzistej w Krakowie. Sam układ przestrzenny ma swoje analogie do morawskiego Pavlova I (Verpoorte 2001). Jednakże pozostałości ognisk ze stref B i C na ulicy Spadzistej prezentują się znacznie skromniej, gdyż ograniczają się do węgli drzewnych oraz popiołów. Z całego kompleksu jedynie w strefie D odnotowano długotrwałe struktury ognisk, charakteryzujące się dużym nagromadzeniem przepalonego materiału kostnego. W przypadku stanowisk B i C procesy soliflukcyjne uniemożliwiają formułowanie szczegółowych konkluzji (Kozłowski, Sobczyk 1987; Sobczyk 1995).

Na uwagę zasługuje także stanowisko kultury oryniackiej Góra Puławska II (pow. puławski, woj. lubelskie), gdzie dobrze zachowały się pozostałości po czterech ogniskach częściowo zniszczonych przez urwisko rzeczne. Paleniska to akumulacje węgli drzewnych w kształcie dużych, cienkich, poziomych soczew, stykających się ze sobą. Na obrzeżach tych obiektów występowały krzemienie i być może kości zwierzęce, które po długotrwałym procesie odwapnienia uległy rozkładowi zachowując się jedynie w postaci nikłych negatywów. Obecne przy paleniskach artefakty świadczą o tym, że aktywność ludności oryniackiej być może skupiała się na małych powierzchniach blisko palenisk, co mogło być spowodowane użytkowaniem obozowiska w okresie zimowym (Siedziba paleolityczna 1911; Krukowski 1939-1948; Chmielewski 1975; Kozłowski, Kozłowski 1977).

Śladom po działaniu ognia niekiedy towarzyszą inne obiekty, tj. jamy, konstrukcje mieszkalne etc. Na ziemiach polskich odnotowano osiem takich stanowisk, przy czym aż na pięciu zaobserwowano powiązania między wspomnianymi obiektami nieruchomymi a pozostałościami palenisk, ograniczającymi się najczęściej do akumulacji węgli drzewnych (tab. 6). 
Tabela 6. Inne konstrukcje nieruchome, występujące na górnopaleolitycznych stanowiskach w Polsce, na których zachowały się pozostałości po działaniu ognia

\begin{tabular}{|c|c|c|}
\hline Stanowisko & $\begin{array}{c}\text { Konstrukcje nieruchome bez powiązań } \\
\text { ze śladami ognia }\end{array}$ & $\begin{array}{l}\text { Obiekty nieruchome } \\
\text { ze śladami ognia }\end{array}$ \\
\hline $\begin{array}{l}\text { Dzierżysław, } \\
\text { stanowisko } 1\end{array}$ & $\begin{array}{l}\text { konstrukcja złożona z dużych głazów, ukła- } \\
\text { dających się w owal, częściowo zniszczona } \\
\text { prze zaburzenia soliflukcyjne; znajdowała } \\
\text { się na głębokości } 204-260 \mathrm{~cm} \text {; interpreto- } \\
\text { wana jako obiekt mieszkalny } \\
\end{array}$ & \\
\hline $\begin{array}{l}\text { Kraków, } \\
\text { ul. Spadzista B }\end{array}$ & & $\begin{array}{l}\text { dwa obiekty mieszkalne(?), } \\
\text { utworzone z nagromadzenia kości } \\
\text { mamutów; w ich sąsiedztwie zaob- } \\
\text { serwowano ślady paleniska }\end{array}$ \\
\hline $\begin{array}{l}\text { Pietraszyn, } \\
\text { stanowisko } 11\end{array}$ & & $\begin{array}{l}\text { przypuszczalnie obiekt mieszkal- } \\
\text { ny zachowany w postaci ciemnej } \\
\text { smugi, być może też pozostałość } \\
\text { po rozwleczonym ognisku, z uwagi } \\
\text { na występujące tam węgle drzewne } \\
\text { (informacje z notatek G. Raschkego) }\end{array}$ \\
\hline $\begin{array}{c}\text { Ćmielów, } \\
\text { stanowisko } 95\end{array}$ & & $\begin{array}{c}\text { trzy obiekty, w dwóch wystąpiły } \\
\text { rozmyte ślady węgli drzewnych; } \\
\text { brak szczegółów (wg Przeździecki } \\
\text { i in. 2011) }\end{array}$ \\
\hline $\begin{array}{l}\text { Dzierżysław, } \\
\text { stanowisko } 35\end{array}$ & & $\begin{array}{l}\text { konstrukcja mieszkalna o układzie } \\
\text { centralnym, z nagromadzeniem } \\
\text { licznych otoczaków, zagłębiona oko- } \\
\text { ło } 55-60 \mathrm{~cm} \text { w podłoże; przylegało } \\
\text { do niej ognisko }\end{array}$ \\
\hline $\begin{array}{c}\text { Mosty, } \\
\text { stanowisko } 13\end{array}$ & & $\begin{array}{l}\text { pięć jam; dwie (obiekty I, II) } \\
\text { interpretowane jako konstrukcje } \\
\text { mieszkalne; we wnętrzu obiektu I } \\
\text { nagromadzenie węgli drzewnych }\end{array}$ \\
\hline $\begin{array}{c}\text { Schronisko } \\
\text { Krucza Skała } \\
\end{array}$ & $\begin{array}{l}\text { rodzaj posadzki utworzonej z płytek } \\
\text { kamiennych }\end{array}$ & \\
\hline $\begin{array}{l}\text { Wołowice, } \\
\text { stanowiska } 1 \text { i } 2\end{array}$ & szyb kopalny & \\
\hline Razem & 3 & 5 \\
\hline
\end{tabular}

Szczególnym przykładem wydaje się być obiekt mieszkalny z Dzierżysławia (stanowisko 35), do którego przylegało palenisko zachowane w postaci nagromadzenia przepalonych kości zwierzęcych (Ginter i in. 2002; Połtowicz-Bobak 2013). Na podstawie takiego układu można przypuszczać, że było to ognisko domowe, przy którym koncentrowało się życie łowców (Schmieder 1988). W przypadku innego, lecz krótkotrwałego obozowiska w Mostach (stanowisko 13, pow. kielecki, woj. świętokrzyskie) odnotowano kilka obiektów nieruchomych. Dwa z nich interpretowane są jako pozostałości po konstrukcjach mieszkalnych. Warto dodać, że we wnętrzu jednego 
z nich (obiekt I) znajdowało się nagromadzenie węgli drzewnych i brunatnego piasku - prawdopodobnie pozostałości ogniska (Cyrek 1986). Opisane rozplanowania przestrzenne mają analogie na francuskim stanowisku Éitolles (Julien 1988; Taborin 1988; Olive i in 1991).

Przedstawione powyżej wyniki dostarczają informacji o wykorzystywaniu ognia w górnym paleolicie. Niedostateczna baza źródłowa nie pozwala na szczegółową analizę zróżnicowania palenisk, ich funkcji i położenia w obrębie stanowiska. Dostępne dane potwierdzają jednak stałe znaczenie ognia i jego wielostronne wykorzystywanie przez grupy paleolitycznych łowców.

\section{ZAKOŃCZENIE}

Powyższe zestawienie pokazuje, że na polskich stanowiskach górnoi wczesnoschyłkowopaleolitycznych ślady ognia są nieliczne i ograniczają się do typowych pozostałości (węgle drzewne, przepalone krzemienie, kości, sedyment i paleniska). Obozowiska, na których dobrze zachowały się układy przestrzenne z jednym lub kilkoma paleniskami należą do rzadkości. Najwięcej śladów działania ognia znaleziono na stanowiskach kultury magdaleńskiej, co odpowiada też ogólnie większej liczbie stanowisk tego technokompleksu w porównaniu z wcześniejszymi jednostkami taksonomicznymi. Na stanowiskach kultury szeleckiej, która w Polsce reprezentowana jest tylko przez kilka stanowisk (Dzierżysław, stanowisko 1, Lubotyń, stanowisko 11, Jaskinia Obłazowa, Jaskinia Mamutowa i Kraków-Zwierzyniec), dobrze zachowane struktury osadnicze wraz ze śladami palenia ognia zarejestrowano na aż dwóch stanowiskach - w Dzierżysławiu (Kozłowski 1964) i Lubotyniu (Połtowicz-Bobak i in. 2013). Zaskakująca jest natomiast skromna liczba takich pozostałości dla kultury hamburskiej, ograniczająca się przede wszystkim do przepalonych krzemieni.

Badania śladów ognia potwierdzają, że odgrywał on znaczącą rolę w życiu prahistorycznych ludzi, jednocześnie pozwalają one na lepsze uchwycenie struktur nieruchomych w górnopaleolitycznych obozowiskach wraz z możliwością wydzielenia stref aktywności bądź wypoczynku. Ich analizy mają duże znaczenie w rekonstrukcji przeszłości, dlatego rozważania tego problemu na szerszą skalę wydają się być ważne. Zagadnienie wykorzystywania ognia w starszej epoce kamienia wymaga szczegółowszych badań dla każdej z kultur, dodatkowo niezmiernie ważne wydaje się poszerzenie bazy źródłowej dotyczącej tego tematu. 


\section{LITERATURA}

Alperson-Afil N.

2012 Archaeology of fire: methodological aspects of reconstructing fire history of prehistoric archaeological sites, Earth-Science Reviews, t. 113, s. 111-119.

Bobak D., Kozłowski S. K., Terberger T., Połtowicz-Bobak M.,

2013 Wstępne sprawozdanie z badań archeologicznych na terasie przed Jaskinia Maszycka w 2013 roku, Prądnik. Prace i materiały Muzeum im. prof. Władysława Szafera, t. 23, s. 141-148.

Bobak D., Łanczot M., Nowak A., Połtowicz-Bobak M., Tokarczyk S.

2010 Wierzawice, st. 31 - nowy ślad osadnictwa magdaleńskiego w Polsce południowo-wschodniej, Materiały i Sprawozdania Rzeszowskiego Ośrodka Archeologicznego, t. 21, s. 63-78.

Bocheński Z., Ginter B., Kozłowski J. K., Mook W. G., Muszyński M., Nadachowski A., Stworzewicz E., Szyndler Z.

1985 Badania osadów schronisk podskalnych w Zalasie koło Krakowa, Folia Quaternaria, t. 56, s. 3-56.

Burdukiewicz J. M.

1980 Wyniki badań stanowiska kultury hamburskiej w Olbrachcicach, gm. Wschowa, woj. Leszno, Sprawozdania Archeologiczne, t. 32, s. 9-27.

Chmielewski W.

1958 Stanowisko paleolityczne w Dziadowej Skale koło Skarżyc w powiecie zawierciańskim, Prace i Materiały Muzeum Archeologicznego i Etnograficznego w Łodzi, Seria Archeologiczna, nr 3, s. 5-62.

1975 Paleolit środkowy i górny, [w:] Prahistoria ziem polskich, t. 1: Paleolit i mezolit, red. W. Chmielewski, W. Hensel, Wrocław, s. 9-158.

Cyrek K.

1986 Magdaleńskie obozowisko w Górach Świętokrzyskich (Mosty, stanowisko 13), Acta Archaeologica Carpathica, t. 25, s. 11-55.

1994 Wstępne wyniki badań wykopaliskowych w schronisku Krucza Skała (Kostkowice st. 1, woj. częstochowskie), Łódzkie Sprawozdania Archeologiczne, t. 1, s. 5-16.

2002 Plastyka paleolityczna z jaskiń i schronisk pólnocnej części Wyżyny Krakowsko-Częstochowskiej, [w:] Sztuka pradziejowa ziem polskich. Katalog wystawy, red. T. Janiak, Gniezno, s. 41-46.

2010 Die Spuren der Magdalenischen Kultur im mittleren Tiel des Polnischen Jura, [w:] The Magdalenian in Central Europe. New Finds and Concepts, red. M. Połtowicz-Bobak, D. Bobak, s. 35-45. 
Cyrek K., Nadachowski A., Madeyska T., Bocheński Z., Tomek T., Wojtal P., Miękina B., Lipecki G., Garapich A., Rzepik-Kowalska B., Stworzewicz E., Wolsan M., Godawa J., Kościów R., Fostowicz-Frelik L., Szyndlar Z.

2000 Excavation in the Deszczowa Cave (Kroczyckie Rocks, Częstochowa Upland, Central Poland), Folia Quaternaria, t. 71, s. 5-84.

Dagnan A., Ginter B.

1970 Wyniki badań na stanowisku górnopaleolitycznym w Wójcicach, pow. Gródków, Sprawozdania Archeologiczne, t. 22, s. 31-37.

Dagnan-Ginter A.

1975 Wielokulturowa pracownia krzemieniarska w Wołowicach, pow. Kraków, Sprawozdania Archeologiczne, t. 27, s. 11-25.

Daniau A-L., D’Errico F., Sánchez Goñ M. F.

2010 Testing the hypothesis of fire use for ecosystem management by $\mathrm{Ne}$ anderthal and Upper Palaeolithic modern human populations, PLoS ONE, t. 5, z. 2, s. 1-10.

Flas D.

2008 La transition du Paléolithique moyen au supérieur dans la plaine septentrionale de l'Europe, Anthropologica et Praehistorica, t. 119, s. 256.

Ginter B.

1969 Archeologiczne badania wykopaliskowe w Brzoskwini, pow. Chrzanów, w latach 1966 i 1967, Sprawozdania Archeologiczne, t. 21, s. 19-20.

Ginter B., Połtowicz M., Pawlikowski M., Skiba S., Trąbska J., Wacnik A., Winiarska-Kabacińska M., Wojtal P.

2002 Dzierżysław 35 stanowisko magdaleńskie na przedpolu Bramy Morawskiej, [w:] Starsza i środkowa epoka kamienia w Karpatach polskich, red. J. Garncarski, Krosno, s. 111-145.

Ginter B., Połtowicz M., Pawlikowski M., Skiba S., Trąbska J., Wacnik A., Winiarska-Kabacińska M., Wojtal P.

2005 Dzierżysław (Dirschel) 35 - ein neper Fundplatz des Magdalénien in Oberschleisen, Archäologisches Korrespondenzblatt, t. 35, s. 431-446.

Jastrzębski S., Libera J.

1987 Stanowisko późnomagdaleńskie w Klementowicach-Kolonii w świetle badań 1981-1982 r., Sprawozdania Archeologiczne, t. 39, s. 9-52.

Julien M.

1987 Activités saisonnières et déplacements des Magdaléniens dans le Bassin Parisien, [w:] Le Magdalénien en Europe, Actes du Colloque de Mayence, Liège, s. 177-189.

1988 L’usage du feu á Pincevent (Siene-et-Marne, France), [w:] Jungpaläolithische siedlungsstrunhtuzen in Europe. Kolloquium 8-14 Mai 1983 Reisensburg/Günzbung, Urgeschichtliche Materialhefte 6, Tübingen, s. $161-168$. 
Kabaciński J., Bratlund B., Kubiak L., Makowiecki D., Schild R., Tobolski K.

1999 The Hamburgian settelement at Mirkowice: recent results and research perspectives, Folia Quaternaria, t. 70, s. 211-238.

Kabaciński J., Kobusiewicz M.

2009 Kragola, stanowisko 25 (AUT 381), [w:] Późny paleolit i mezolit w dorzeczu środkowej Warty, t. 1, red. J. Kabaciński, I. Sobkowiak-Tabaka, Poznań, s. 18-52.

Le feu apprivioisé

1987 Le feu apprivioisé. Le feu dans la vie quotidienne des homes préhistoriques, red. C. Parlés, Musée Paris.

Kobusiewicz M.

1975 Stanowisko kultury hamburskiej w Linach, pow. Wolsztyn, Światowit, t. 34, s. 213-237.

Kowalski S.

1967 Wstępne wyniki badań archeologicznych w jaskini Mamutowej prowadzonych w latach 1957-1964, Materiały Archeologiczne, t. 8, s. 47-60.

Kozłowski J. K.

1960 Pradzieje powiatu krakowskiego, Kraków.

1964 Paleolit na Górnym Śląsku, Wrocław.

Kozłowski J. K., Kozłowski S. K.

1977 Epoka kamienia na ziemiach polskich, Warszawa.

Kozłowski J. K., Sobczyk K.,

1987 The upper paleolithic site Kraków-Spadzista Street C2: excavations 1980, Prace archeologiczne, t. 42, s. 7-68.

Krukowski S.

1939-1948 Paleolit, [w:] Prahistoria ziem polskich, red. S. Krukowski, J. Kostrzewski, R. Jakimowicz, Warszawa-Kraków.

Leesch D., Bullinger J., Cattin M.-I., Müller W., Plumettaz N.

2010 Hearths and hearth-related activities in Magdalenian open-air sites: the case studies of Champréveyres and Monruz (Switzerland) and their relevance to an understanding of Upper Palaeolithic site structure, [w:] The Magdalenian in Central Europe. New finds and concepts, red. M. Połtowicz-Bobak, D. Bobak, Rzeszów, s. 53-69.

Olive M.

1988 Une habitation magdalénienne d'Étiolles: l'unité, P 15, Paris.

Olive M., Pigeot N., Taborin Y.

1991 Il y a 13000 ans a Étiolles, Paris.

Połtowicz M.

2004 Ślady łowców mamutów i wyspecjalizowanych myśliwych na terenie Przemyśla, [w:] Dzieje Przemyśla, t. 1: Osadnictwo pradziejowe i wczesnośredniowieczne, cz. 2: Analiza źródel i synteza, red. A. Koperski, Przemyśl, s. 5-17. 
Połtowicz-Bobak M.

2013 Wschodnia prowincja magdalenienu, Rzeszów.

Połtowicz-Bobak M., Bobak D., Badura J., Wacnik A., Cywa K.

2013 Nouvelles données sur le Szélétien en Polotne, [w:] Le Paléolithique supérieur ancien de l'Europe du Nord-Ouest. Réflexions et synthèses à partir d'un projet collectif de recherche sur le centre et le sud du Bassin parisien. Actes du colloque de Sens (15-18 avril 2009), red. P. Bodu $\mathrm{i}$ in., Paris, s. 485-496.

Przeździecki M., Migal W., Krajcarz M., Pyżewicz K.

2011 Obozowisko kultury magdaleńskiej na stanowisku 95 „Mały Gawroniec” w Ćmielowie pow. ostrowiecki, woj. świętokrzyskie, Światowit, t. 8(49), s. 27-34.

Pyżewicz K., Rozbiegalski P.

2011 Sposoby rozpalania ognia w młodszej epoce kamienia na terenie ziem polskich w kontekście badań eksperymentalno-traseologicznych, Światowit, nr 50, s. 259-273.

Roebroeks W., Willa P.

2012 Some reflections on fire usage in the Middle Paleolithic, [w:] Mind set on flint. Studies in honour of Dick Straper, red. M. J. L. Th. Niekus i in., Groningen, s. 49-77.

Rowlett R. M.

2000 Fire control by Homo erectus in East Africa and Asia, Acta Antropologica Sinica, nr 19, s. 198-208.

Sandgathe D. M., Dibble H. L., Goldberg P., Turq A., Niven L., Hodgkins J.

2011 On the role of fire in Neandertal adaptations in Western Europe: evidence from Pech de l'Azé IV and Roc de Marsal, France, PaleoAnthropology 2011, s. 216-148.

Schmider B.

1988 Les habitations magdaléniennes de Marsangy (Valle de L’yonne), [w:] Jungpaleolithische siedlungsstrunhtuzen in Europe. Kolloquium 8-14 Mai 1983 Reisensburg/Günzbung Yrgeschichfliche Materialhefte 6, Tübingen, s. 169-186.

Siedziba paleolityczna

1911 Siedziba paleolityczna na Górze Puławskiej na lewym brzegu Wisły, [w:] Polska przedhistoryczna, oprac. S. J. Czarnowski, Warszawa-Kraków.

Sobczyk K.

1993 The late palaeolithic flint workshop at Brzoskwinia-Krzemionki near Kraków, Kraków.

Sobczyk K.

1995 Osadnictwo wschodniograweckie w dolinie Wisty pod Krakowem, Kraków. 
Sorensen A., Roebroeks W., Gijn van A.

2014 Fire production in the deep past? The expedient strike-a-light model, Journal of Archeological Science, nr 42, s. 476-486.

Stapert D., Johansen L.

1999 Making fire in Stone Age: flint and pyrite, Geologie en Mijnbouw, t. 78, s. $147-164$.

Taborin Y.

1988 Les nouvelles habitations prehistoriques d'Etiolles, (Essonne, France) (fouilles juin-juillet 1982), [w:] Jungpaläolithische siedlungsstrunhtuzen in Europe. Kolloquium 8-14 Mai 1983 Reisensburg/Günzbung, Urgeschichtliche Materialhefte 6, Tübingen, s. 133-141.

Terberger T.

1997 Die Siedlungsbefunde des Magdalenien-Fundplatzes Gönnersdorf Konzentrationen III und IV, Stuttgart.

Valoch K.

1993 Vedrovice V, eine Siedlung des Szeletiens in Sudmiihren, Quartär, t. 43/44, s. 7-93.

Vaquero M., Pastó I.

2001 The definition of spatial units in Middle Paleolithic sites. The hearthrelated assemblages, Journal of Archaeological Science, t. 28, s. 12091220.

Verpoorte A.

2001 Places of art, traces of fire. A contextual approach to anthropomorphic figurines in the Pavlovian (Central Europe, 29-24 kyr BP), Archaeological Studies Leiden University, t. 8, Leiden.

Wilczyński J.

2009 Targowisko - a new Late Glacial site in Southern Poland, Eurasian Prehistory, t. 6, s. 95-118.

Wiśniewski A.

2006 Środkowy paleolit w dolinie Odry, Wrocław.

Wiśniewski T. Mroczek P., Rodzik J., Zagórski P., Wilczyński J., Nývltová-Fišáková M.

2012 On the periphery of the Magdalenian World: An open-air site in Klementowice (Lublin Upland, Eastern Poland), Quaternary International, t. $272-273$, s. $308-321$. 


\title{
REMAINS OF FIRE ACTIVITY IN SITES \\ OF UPPER AND FINAL UPPER PALAEOLITIHC IN POLAND
}

\begin{abstract}
Summary
The text contained the present analysis of the remains of fire's activity for: Jerzmanowician, Szeletian, Aurignacian, Gravettian, Magdalenian and Hamburgian Cultures from the current Polish area. The remains, which were recorded are: charcoals, burned loesses, stones and bones, and hearths. The most characteristic the hearths are often difficult to unambiguous interpretation, despite the fact that some residues ie. burned sediment and stone slab provide a possibility of doing some interpretations of such objects. Above the traces of fire's activity on some positions from the Polish lands present themselves extremely unique, eg. Wierzawice, Deszczowa Cave and Krucza Skała Shelter (the hearth with stone slabls around) Lubotyń, site 11, Targowisko (accumulation of several hearths) and Dzierżysław, site 35 (fireplace nerby dwelling structures).
\end{abstract}

Translated by Ewa Józefowicz

Adres do korespondencji:

Karolina Szpunar

Instytut Archeologii, Uniwersytet Rzeszowski

ul. Moniuszki 10, 35-015 Rzeszów

karolinaszpunar@o2.pl 